\title{
FORMULASI RECHTSVINDING DENGAN PENALARAN ANALOGIS DALAM EPISTEMOLOGI HUKUM ISLAM \\ (Telaah Metodologis Qiyas sebagai Ra'y terhadap Mashâdir al-Ahkâm asy-Syar'iyyah)
}

\author{
Muhammad Syarif Hidayatullah \\ Program Doktor Ilmu Syariah Pascasarjana UIN Antasari Banjarmasin \\ e-mail: syarif.muhammad849@gmail.com

\begin{tabular}{|l|l|l|}
\hline Submit: 02-11-2020 & $\begin{array}{l}\text { Direvisi: 04, 13, 26-11- } \\
2020\end{array}$ & Dipublish: 18-12-2020 \\
\hline
\end{tabular}

Abstract: Qiyas is one of the methods of legal discovery in the epistemology of Islamic law that can be applied in describing contemporary cases with analogical forms of reasoning. This paper aims to describe qiyas as a method of legal discovery. This type of research is normative legal research with a conceptual approach. The results of the discussion showed that the discovery of the law through qiyas is built on four elements that become the pattern of the formation of the law, namely ashl, far', bukm al-ashl and ' illat. The law can be found when there is a common legal motive ('illat) between a legal case that has no direct provision in the nash (far') and a legal case that has been established in nash (ashl). In the process of qiyas application there is also a search for legal motives (masalik al-illat), because there is 'illat listed in nash ('illat manshushah) and which is not listed in the nash/results istinbath (illat mustanbathah). Qiyas in the study of conventional legal theory methodologically has the same pattern of legal discovery as argumentum per analogium which is part of the legal construction method.

Kata kunci: Rechtsvending, Dalil Hukum, Qiyas, Ijtihad, Mashâdir al-Ahkâm

\section{PENDAHULUAN}

$\mathcal{P}$ erkara hukum (syariah) dalam ajaran Islam tidak hanya mengarah pada pembahasan ibadah, namun juga mencakup muamalah. Sebab aturan hukum Islam itu universal dan komprehensif yang menyentuh berbagai aspek kehidupan baik itu ritual maupun interaksi sosial. Islam adalah agama rahmatan lil âlamîn (rahmat bagi seluruh alam) dengan syariat yang menyeluruh dan sempurna yang bermuara pada mashâdir al-ahkâm asy-syar'iyyah

atau sumber hukum Islam yakni al-Qur'an dan sunnah.

Selain istilah mashâdir al-ahkâm asysyar'iyyah dikenal pula istilah al-adillah asy-syar'iyyah (اللأدللة الثرعية) atau dalil-dalil hukum Islam. Istilah mashâdir al-ahkâm asy-syar'iyyah tidak ditemukan dalam khazanah fikih klasik, melainkan yang ada adalah sebutan dalil atau al-Adillah asy-syar'iyyah, sedangkan istilah mashâdir al-ahkâm terdapat dalam literatur fikih kontemporer. (Sulistiani, 2018)

Sumber hukum dalam ajaran Islam adalah al-Qur'an dan Sunnah. Selain alQur'an dan Sunnah terdapat pula dalil hukum sekunder yakni ijtihad. Jadi secara umum dapat dirumuskan, bahwa dalil hukum dalam syariat Islam ada dua, yakni: pertama, nash/wahyu atau disebut dalil naqli yang meliputi al-Qur'an dan Sunnah. Kedua, ijtihad/ra'y/penalaran 
atau disebut dalil aqli yang meliputi $i j m \hat{a}^{\prime}$, qiyâs, mashlahah mursalah, istihsân, istishhâb, 'urf, sad adz-dzarî'ah, madzhab shahâbî/qaul shahâbî, dan syar'u man qablanâ. Dalil hukum berupa ijtihad dalam kajian ushul fikih, secara spesifik terbagi lagi menjadi dua bagian/kelompok, yakni adillah alahkâm al-muttafaq 'alaihâ (أدلة الأحكام المتفق (عليها ) atau dalil-dalil hukum yang disepakati meliputi ijmấ dan qiyâs dan adillah al-ahkâm al-mukhtalaf fihâ ( أدلة المختلف فيها) atau dalil-dalil hukum yang diperselisihkan meliputi selain ijmấ dan qiyâs. Ijmấ dan qiyâs sudah diakui oleh jumhur ulama, namun kalangan mazhab dan para fukaha berbeda pandangan mengenai legalitas dan ruang lingkup bentuk-bentuk penalaran lain yang bersumber dari ijtihad. (Kamali, 2008)

Upaya yang dilakukan para ulama dalam menggali, memahami dan menetapkan serta merumuskan hukum Islam yang bersumber dari al-Qur'an dan sunnah dikalangan para ulama ushîl disebut dengan istinbath. (Dedi, 2018) Dalil hukum sekunder (dalil naqli) berupa $r a^{\prime} y$ dengan bagian-bagiannya ini dalam upaya dan langkah-langkah ijtihad disebut juga sebagai metode penemuan hukum atau thuruq istinbath al-ahkâm. (Simbolon, 2020)

Pada kajian hukum konvensional, penemuan hukum dikenal dengan istilah rechtsvinding. Rechtsvinding merupakan proses pembentukan hukum oleh hakim/aparat penegak hukum lainnya dalam penerapan peraturan umum terhadap peristiwa hukum yang konkrit dan hasil penemuan hukum menjadi dasar untuk mengambil keputusan ("Penemuan hukum oleh hakim (Rechtvinding)," t.t.). Penemuan hukum dalam konteks ini biasanya didefinisikan sebagai proses pembentukan hukum oleh hakim atau petugas-petugas hukum lainnya yang diberi tugas melaksanakan hukum terhadap peristiwa hukum yang konkrit. (Nur, 2016) Selain itu pula dapat dibawa ke pemaknaan sebagai suatu proses konkretisasi atau individualisasi peraturan hukum (das sollen) yang bersifat umum dengan mengingat akan peristiwa kongkrit (das sein) tertentu. (Nur, 2016)

Fenomena sosial dengan berbagai peristiwa yang menyertainya serta kebutuhan hidup yang kompleks berjalan dinamis sehingga bermunculan persoalanpersoalan baru yang tidak ditemukan penjelasan yang terperinci dan khusus dalam nash. (Naya, 2017) Eksistensi fatwa di tengah masyarakat dalam rangka menjawab persoalan yang dihadapi umat terutama pada kasus-kasus kontemporer memiliki urgensi dan signifikansi yang dapat dilihat pada fungsi yang dijalankan sebagai mediasi antara idealitas hukum Islam di satu sisi dan realitas faktual disisi lain. (Suryani, 2018) Melihat fakta demikian, maka eksistensi ijtihad menjadi sangat penting dan perlu dilakukan dalam merespons problematika kontemporer agar tidak terjadi kekosongan hukum dan dapat memberikan jawaban atas persoalan yang terjadi memperhatikan kaidah-kaidah bahasa (linguistik) maupun kaidah-kaidah ushuliyah lainnya. (Zaidah, 2018)

Ijtihad dalam bentuknya sebagai upaya pengeluaran hukum dari sumbernya, selain pengambilan hukum dari zhahir nash jika hukum itu didapatkan dari nash, juga terdapat pengambilan hukum dari ma'qul nash, karena nash itu mengandung 'illat yang menjelaskannya, atau 'illat itu diketahui dan tempat kejadian yang di dalamnya mengandung 
'illat, sedang nash itu tidak memuat hukum itu maka inilah yang disebut dengan qiyas. (Erwan, 2018)

Qiyas merupakan metode penemuan hukum melalui menyamakan hukum sesuatu yang tidak ada ketentuan hukumnya dengan sesuatu yang ada hukumnya karena adanya persamaan 'illat antara keduanya. (W. az Zuhailî, 1999) Maka demikian, penalaran ijtihad dalam konteks rechtvinding (penemuan hukum) sebagaimana qiyas perlu dilakukan dalam menyingkap kepastian hukum dan menjelaskan status hukum kasus-kasus yang menjadi persoalan umat dan memerlukan jawaban yang tepat dan tidak keluar dari koridor syariah.

Berkembangnya zaman secara dinamis, maka banyak hal baru yang ditemui dan menjadi problematika yang dihadapi dalam perkara muamalah. Fikih Islam melalui kaidah fikih mengakomodir perkara muamalah dengan kaidah prinsip dasarnya yakni hukum asalnya adalah halal atau boleh, terkecuali ada dalil yang melarangnya. (al Qaradhâwî, 2010: asy Syuraim, 1994)

Lalu kaidah ushul berbunyi (Usman, 1997):

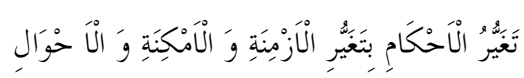

"Perubahan hukum itu berdasarkan perubahan zaman, tempat dan keadaan."

Dalam kaidah ushul lainnya (al Asmarî, 2000; al Bâqistânî, 2002; an Nadawî, 1999):

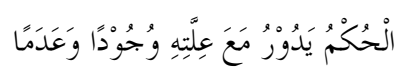

"Hukum berputar (berlaku) bersama ada atau tidak adanya 'illat."

Illat (sebab hukum) merupakan bagian dari nalar qiyas. Dengan demikian, kedudukan qiyas menjadi sentral sebagai bagian dari penalaran atau $r a^{\prime} y$ terhadap mashâdir al-ahkâm asy-syar'iyyah (al-Qur'an dan sunnah), apalagi arus modernisasi, perkembangan dan kemajuan teknologi, kondisi yang dinamis dan kompleksitas kebutuhan masyarakat serta pergeseran perilaku sosial melahirkan banyak persoalan baru yang menuntut untuk dilakukannya qiyas sebagai upaya pemecahan masalah dan menjawab persoalan yang dihadapi umat dalam muamalah kontemporer (kekinian). Dikarenakan munculnya kasus-kasus baru yang belum ada ketetapan hukumnya dalam nash akan membuat kebingungan dan keragu-raguan umat Islam apakah hal tersebut boleh ataukah tidak boleh, sebab mereka memerlukan jawaban oleh para ulama terhadap status hukumnya. Oleh karena itu, eksistensi qiyas sebagai $r a^{\prime} y$ terhadap mashâdir alahkâm asy-syar'iyyah sebagai upaya penemuan hukum dalam memberikan kepastian hukum melalui formulasi fikih (produk hukum) terkait problematika kontemporer adalah sangat urgen untuk dilakukan. Namun demikian, eksistensi qiyas sebagai penalaran ijtihad dan metode penemuan hukum tidak dapat diaplikasikan sembarangan dengan asal mengqiyaskan kasus hukum yang satu dengan yang lainnya secara bebas, melainkan terdapat standar dan aturan secara metodologis yang menjadi sandaran dalam prosedur serta proses alur berpikir yang membentuk pola pembentukan hukumnya yang telah diformulasikan oleh para ulama ushul fikih.

Terminologi rechtsvinding dalam hukum konvensional dipahami sebagai 
penemuan hukum oleh hakim, karena memang otoritas dalam penemuan hukum berada di tangan hakim sebagai pihak yang memiliki otoritas dalam menjalankan suatu aturan hukum, dalam hal ini tanpa bermuara pada al-Qur'an dan sunnah sebagaimana hukum Islam, tapi muaranya adalah peraturan perundang-undangan. Penemuan hukum dalam kajian ushul fikih disebut istinbâth al-hukm yang dilakukan oleh seorang ulama mujtahid yang dalam setiap putusan hukumnya tidak lepas dari alQur'an dan sunnah. Maka terminologi rechtsvinding dalam tulisan ini dalam pemaknaan sebagai metode penemuan hukum atau upaya pembentukan hukum dan diarahkan pada penemuan hukum dalam menghadapi kasus hukum oleh seorang ulama mujtahid atau ahli hukum Islam (figh dan ushîl figh). Penemuan hukum dalam teori hukum konvensional dikenal istilah metode interpretasi dan konstruksi, (Nur, 2016) atau dalam tipologi lain yakni metode interpretasi, metode argumentasi dan metode penemuan hukum bebas. (Bakhtiar, 2018)

Penemuan hukum dalam teori hukum konvensional secara metodologi dan alur berpikir dapat memiliki kesamaan dengan penemuan hukum dalam teori hukum Islam (ushûl figh), namun secara fundamental dan substansial tetap ada perbedaan. Maka dalam tulisan ini, penulis berupaya mengkaji alur berpikir dan pola kerja penemuan hukum melalui penalaran analogis (qiyas) dalam hukum Islam. Qiyas merupakan salah satu dari adillah alahkâm al-muttafaq 'alaihâ atau penggunaan $r a^{\prime} y$ sebagai dalil hukum yang disepakati jumhur ulama. Berbeda halnya dengan istihsân dan mashlahah mursalah yang termasuk adillah al-ahkâm al-mukhtalaf fîhâ atau dalil hukum yang masih diperselishkan. Penggunaan $r a^{\prime} y$ berupa metode istihsân yang disokong oleh Imam Abû Hanîfah, keberadaannya ditolak oleh Imam Syâfi'î (Naya, 2016; Tajudin, 2017), atau mashlahah mursalah yang digunakan oleh Imam Mâlik sebagai sumber hukum, namun tidak digunakan sebagai sumber hukum oleh Imam Syâfi'î. (T. Rohman, 2017) Dengan demikian, kajian ini berupaya menyingkap standard operating procedure secara metodologis $r a^{\prime} y$ atau penalaran qiyas sebagai rechtosinding dalam epistemologi hukum Islam.

\section{METODE PENELITIAN}

Metode penelitian yang digunakan adalah penelitian hukum normatif dengan pendekatan konseptual, yakni menelaah konsep qiyas sebagai metode rechtsvinding (penemuan hukum) atau itinbâth al-hukm dalam epistemologi hukum Islam. Penggalian bahan hukum dalam penelitian ini dilakukan dengan studi literatur melalui kitab-kitab ushul fikih baik klasik maupun kontemporer. Selain itu bahan hukum pula digali pada jurnal-jurnal ilmiah yang berkaitan dengan objek kajian dan kamus yang digunakan dalam pendefinisian secara etimologis. Analisis yang dilakukan dalam penelitian ini bersifat deskriptif dengan menggunakan logika deduktif.

\section{FORMULASI RECHTSVINDING (PENE- MUAN HUKUM) DENGAN METODE QIYAS DALAM EPISTEMOLOGI HUKUM ISLAM}

\section{Pengertian Qiyas}

Qiyas merupakan bentuk masdar dari kata قاس - يقيس yang artinya ukuran, 
mengetahui ukuran sesuatu. (Munawwir, 1997) Qiyas secara bahasa bermakna at-taqdîr (mengukur) dan attaswiyah (menyamakan). Maka qiyas dapat diartikan mengukur sesuatu dengan yang lainnya maupun menyerupakan atau menyamakan sesuatu dengan yang sejenisnya. Sedangkan secara istilah oleh para ulama ada berbagai pendapat dalam keragaman redaksi pendefinisiannya.

Menurut Fakhruddîn ar-Râzî, qiyas adalah penalaran tentang penetapan perumpamaan bentuk hukum pada bentuk yang lain karena terdapat persamaan 'illat hukum ketika menetapkannya. (ar Râzî, 1994) Lalu alGhazâlî mendefinisikan qiyas adalah menanggungkan sesuatu yang diketahui kepada sesuatu yang diketahui dalam hal menetapkan hukum pada keduanya atau meniadakan hukum dari keduanya disebabkan ada hal yang sama antara keduanya, dalam penetapan hukum atau peniadaan hukum. (al Ghazâlî, 1993) Sementara itu 'Abdul Wahhâb Khallâf berpendapat bahwa qiyas adalah menyamakan suatu hukum dari peristiwa yang tidak memiliki nash hukum dengan peristiwa yang sudah memiliki nash hukum, sebab adanya persamaan dalam 'illat hukumnya. (Khallâf, t.t.) Sedangkan Wahbah az-Zuhailî mengungkapkan qiyas adalah menyamakan hukum sesuatu yang tidak ada ketentuan hukumnya dengan sesuatu yang ada hukumnya karena adanya persamaan 'illat antara keduanya. (W. az Zuhailî, 1999)

Berdasarkan penjelasan para ulama di atas, walaupun dengan redaksi yang berbeda, namun bertemu pada satu makna yang sama yakni titik tolaknya adalah pada penyerupaan sesuatu dengan sesuatu yang lain karena adanya kesamaan illat hukum. Selain itu proses penetapan hukum dengan metode qiyas bukanlah menetapkan hukum dari awal, akan tetapi hanya menyingkapkan dan menjelaskan hukum pada suatu persoalan hukum yang belum jelas hukumnya dengan upaya penggalian atau telaah yang mendalam serta teliti pada 'illat hukum sebagai jalan mendasar yang menjembatani proses qiyas. (Sakirman, 2018) Dengan begitu, pilar mendasar yang penting dalam membangun alur berpikir qiyas atau penalaran analogis dalam hukum Islam pada semua pengertian dan penjelasan para ulama di atas adalah bermuara pada kesamaan 'illat (sebab hukum/motif penetapan hukum) sehingga dapat dilakukannya pengqiyasan (penyerupaan) antara ashl atau induknya yakni kasus yang ada hukumnya secara langsung melalui nash kepada far' atau cabangnya yakni kasus baru dalam realita yang tidak ditemukan hukumnya secara langsung dalam nash.

\section{Kehujjahan Qiyas}

Berdasarkan pendapat jumhur ulama menyatakan bahwasanya qiyas adalah termasuk hujjah syar'iyyah atas hukum-hukum terkait perbuatan manusia ('amaliyah) dan qiyas menduduki martabat yang keempat di antara hujjah-hujjah syar'iyyah setelah al-Qur'an, as-Sunnah, dan ijmấ'. Alasan 
jumhur menerima qiyas menjadi hujjah adalah mendasarkan pada dalil berikut: Allah SWT berfirman dalam QS. an-Nisâ' (4): 59

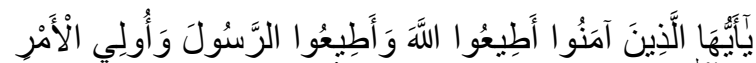

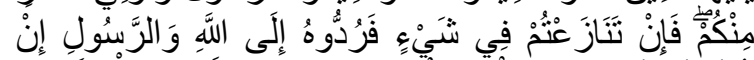

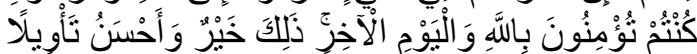

"Hai orang-orang yang beriman, taatilah Allah dan taatilah Rasul (Nya), dan ulil amri di antara kamu. Kemudian jika kamu berlainan Pendapat tentang sesuatu, Maka kembalikanlah ia kepada Allah (Al Quran) dan Rasul (sunnahnya), jika kamu benar-benar beriman kepada Allah dan hari kemudian. Yang demikian itu lebih utama (bagimu) dan lebih baik akibatnya." (QS. an-Nisa'[3]: 59

Allah SWT pula berfirman dalam QS. Al-Hasyr: 2

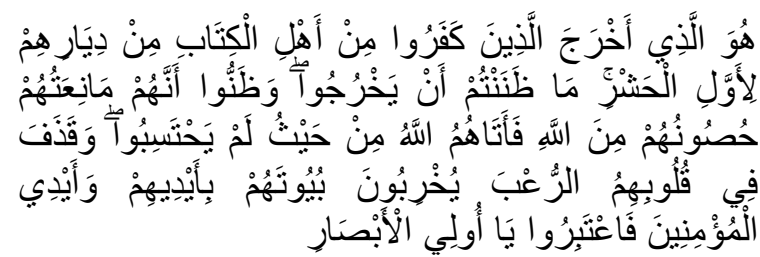

"Dia-lah yang mengeluarkan orangorang kafir di antara ahli kitab dari kampung-kampung mereka pada saat pengusiran yang pertama. Kamu tidak menyangka, bahwa mereka akan keluar dan merekapun yakin, bahwa bentengbenteng mereka dapat mempertahankan mereka dari (siksa) Allah; Maka Allah mendatangkan kepada mereka (hukuman) dari arah yang tidak mereka sangkasangka. Dan Allah melemparkan ketakutan dalam hati mereka; mereka memusnahkan rumah-rumah mereka dengan tangan mereka sendiri dan tangan orang-orang mukmin. Maka ambillah (Kejadian itu) untuk menjadi pelajaran, Hai orang-orang yang mempunyai wawasan." (QS. al- Hasyr [59]: 2)
Kemudian dalam hadits yang menjelaskan tentang Muadz bin Jabal yang diutus Nabi saw. ke Yaman (ad Dârimî, 2000; as Sijistânî, t.t.; asy Syaibânî, 2001; at Tirmidzî, 1998a; ath Thabrânî, 1994):

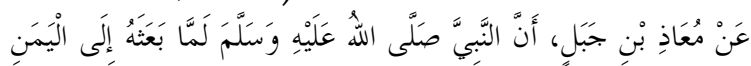

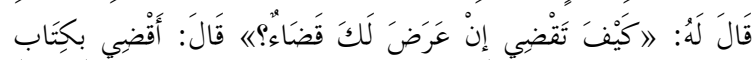

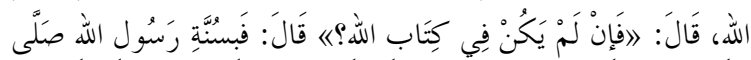

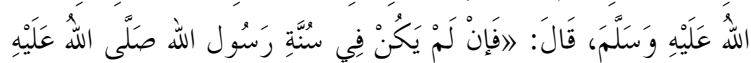

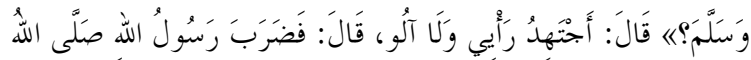

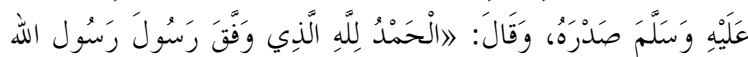

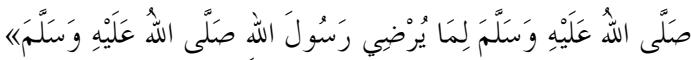
"Dari Muadz bin Jabal ra. Bahwa Nabi saw. Ketika mengutusnya ke Yaman, Nabi berkata: "Apa yang akan kau lakukan bila terjadi perkara yang harus kau hukumi?" Ia menjawab; aku menghukumi berdasarkan yang ada dalam kitab Allah. Rasulullah saw. Berkata: "Bila didalam kitab Allah tidak ada, apa yang akan kau lakukan bila terjadi perkara yang harus kau hukumi?" Ia menjawab; dengan sunnah Rasulullah saw. Rasulullah saw. berkata: "Bila tidak ada dalam sunnah Rasulullah saw.?" Ia menjawab; aku berijtihad dengan pendapatku dan tidak berlebih (dalam berijtihad). Kemudian Rasulullah saw. Menepuk dada Muadz dan berkata; "Segala puji bagi Allah yang memberi pertolongan pada utusan Rasulullah saw. Untuk sesuatu yang diridhai Rasulullah saw." (HR. Abû Dâwud, at Tirmidzî, Ahmad, Ath Thabrani dan ad Dârimî)

Hadis Muadz bin Jabal tatkala diutus Nabi SAW ke Yaman ini menunjukkan bahwasanya dasar hukum yang dipakai adalah al-Qur'an, sunnah dan ijtihad, yang dikehendaki dengan ijtihad adalah kemampuan daya pikiran dan kemampuan lainnya 
menetapkan hukum dengan tetap melihat ketentuan yang telah ada pada nash yakni dengan cara mengqiyasnya. (Amiruddin, 2009) Adapun kelompok yang menolak qiyas sebagai dalil hukum antara lain mazhab Nizhamiyah, Zhahiriyah dan sebagian kelompok syiah yang mereka berpendapat bahwa qiyas bukanlah hujjah syar'iyyah atas hukum. Mereka itulah yang disebut nufatul qiyas (pembuang qiyas). (Khallâf, t.t.) Bahkan Ibnu Hazm dari kalangan Zhahiriyah dengan tegas menyatakan penolakannya terhadap hujjah yang berdasarkan dengan $r a^{\prime} y$ dan hanya bersandar kepada al-Qur'an dan hadits dengan memperhatikan makna dan pengertian lahiriyah (zahirnya) saja (Khoirin, 2018).

\section{Pembagian Qiyas}

Qiyas ditinjau dari segi
perbandingan antara 'illat yang
terdapat pada ashl dengan yang
terdapat pada far', maka qiyas dapat
dibagi sebagai berikut (Farghalî, 1983):
1. Qiyâs aulawî (ولوي), yakni qiyas
dengan 'illat yang ada pada far' lebih
kuat daripada yang ada pada ashl.
2. Qiyâs musâwwîn (فياس مساوي), yakni qiyas
dengan 'illat yang ada pada far'
maupun ashl kualitas diantara
keduanya sama.

3. Qiyâs al-adnâ (قياس الأدنى), yakni qiyas dengan 'illat yang ada pada far' lebih lemah daripada yang ada pada ashl.

Sedangkan jika ditinjau dari segi kejelasan 'illat sebagai landasan hukum, qiyas dapat dibagi sebagai berikut (W. az Zuhailî, 1986):
1. Qiyâs jalî (قياس جلي), yakni qiyas yang 'illatnya ditetapkan oleh nash bersamaan dengan hukum ashl atau tidak ditetapkan 'illatnya namun dipastikan bahwa tidak ada pengaruh perbedaan antara ashl dengan far'.

2. Qiyâs khafî (قياس خفي), yakni qiyas yang 'illatnya tidak disebutkan di dalam nash.

\section{Rukun dan Syarat Qiyas}

Penalaran qiyas dalam aplikasinya harus memenuhi beberapa rukun yang menjadi unsur yang harus ada dalam proses pengqiyasan. Ada empat rukun qiyas yang menjadi pilar-pilar yang membangun metode berpikir penalaran analogis dalam hukum Islam. Rukun-rukun tersebut adalah sebagai berikut: (Khallâf, t.t.)

1. Pokok atau al-ashl (الاصـل) yaitu sesuatu yang ada hukumnya dalam nash. Disebut maqis 'alaih (yang dijadikan ukuran), atau mahmul 'alaih (yang dijadikan pertanggungan), atau musyabbah bih (yang dibuat keserupaan/yang menyerupakan). Syarat al-ashl yakni (Sudirman, 2018): pertama, hukum ashl merupakan hukum yang telah tetap, bukan yang mansukh (sudah dihapuskan)/sudah di-nasakh); kedua, hukum itu ditetapkan berdasarkan syara'; ketiga, ashl itu bukan merupkan far' dari ashl lainnya; keempat, dalil yang menetapkan 'illat pada ashl adalah dalil khusus, tidak bersifat umum; kelima, ashl itu tidak berubah setelah dilakukan qiyas; dan kelima, hukum ashl itu tidak keluar dari kaidahkaidah qiyas. 
2. Cabang atau al-far' (الفرع) yaitu sesuatu yang tidak ada hukumnya dalam nash, tetapi ada maksud menyamakannya kepada al-ashl dalam hukumnya. Disebut al-maqis (yang diukur), atau al-mahmul (yang dibawa) atau musyabbah (yang diserupakan). Syarat al-far' yakni (Zahrah, 1973): pertama, far' merupakan kasus baru yang tidak ada nash hukumnya secara langsung baik dalam al-Qur'an maupun hadits; kedua, 'illat hukum harus terwujud dalam kasus baru, sama jelasnya dengan 'illat pada ashl.

3. Hukum pokok atau hukm al-ashl ( حكم (الاصل yaitu hukum syara' yang ada nashnya menurut ashl (pokok) dan dimaksud dengan ini sebagai pangkal hukum bagi far' (cabang.). Syarat hukm al-ashl yakni (Zahrah, 1973): pertama, ketetapan hukum tersebut merupakan hukum syara' berkenaan dengan amal perbuatan (bersifat 'amaliyah); kedua, ketetapan hukum tersebut merupakan hukum yang rasional yaitu dapat ditelusuri, maksudnya adalah dapat ditangkap sebab dan motif penetapan hukumnya, ataupun mengandung isyarat terhadap sebab-sebab itu.

4. Sebab hukum atau al-'illat (العلة) yaitu keadaan yang dijadikan dasar oleh hukum ashl (pokok) berdasarkan wujudnya keadaan itu pada cabang, maka disamakanlah cabang itu kepada pokok mengenai hukumnya. Ada banyak syarat-syarat yang ditetapkan oleh para ulama ahli ushul fikih sebagai kriteria yang harus dipenuhi agar sesuatu itu dapat disebut sebagai 'illat. Setidaknya dalam permasalahan syarat 'illat ini terdapat 24 syarat yang disebutkan oleh para ulama. 24 syarat ini dijelaskan oleh asySyaukânî dalam kitabnya Irsyâd alFukhûl (asy Syaukânî, 2000), lebih panjang lebar dibahas oleh azZarkasyî dalam kitabnya al-Bahr alMuhîth fî Ushîl al-Fiqh (az Zarkasyî, 1992). Sebagian di antaranya disepakati sedangkan sebagian lainnya ada ikhtilaf (perbedaan pendapat) dikalangan para ulama dalam memandangnya sebagai syarat 'illat. Tâjuddîn as-Subkî secara umum dan mendasar menyebutkan tiga kriteria sifat 'illat (as Subkî, 2003), Athâ' Abû ar-Rasytah menyebutkan sepuluh syarat 'illat (ar Rasytah, 2000), Taqiyuddîn anNabhânî menyebutkan delapan syarat (an Nabhânî, 2003), Khudharî Bik menyebutkan delapan syarat pula (Bik, 1969), sedangkan Wahbah az-Zuhailî menyebutkan enam syarat utama yang baginya syaratsyarat lainnya sudah tercakup dalam enam syarat tersebut (W. az Zuhailî, 1986). Syarat-syarat 'illat antara lain (Sarwat, 2019): pertama, zhahir, yakni 'illat merupakan sifat yang jelas, dapat ditangkap oleh indera dan akal pikiran (dapat diterima secara logis); kedua, Dhabith, yakni 'illat merupakan sifat yang pasti; ketiga, washfan munasiban, yakni 'illat merupakan sifat yang serasi dan pantas, jadi 'illat tidak hanya sesuatu yang pantas dan cocok untuk mewujudkan hikmah yang terkandung dari segi tujuan penetapan hukum, tetapi juga dari segi wujudnya memang pantas sebagai alasan penetapan hukum 
sesuai dengan tujuan syara' yaitu untuk mewujudkan kemaslahatan dan menolak kemudharatan; keempat, 'illat tidak hanya terdapat pada ashl (pokok), tetapi juga terdapat pada far' (cabang), maksudnya bahwa 'illat pada ashl dapat diterapkan pada persoalan lain; kelima, 'illat tidak boleh berlawanan atau menyalahi ketentuan hukum yang ditetapkan oleh nash; keenam, 'illat tidak boleh membatalkan hukum pokok; ketujuh, 'illat merupakan suatu sifat yang mendorong adanya hukum, maka keberadaannya tidak boleh setelah hukum, dengan begitu 'illat dalam penetapannya tidak boleh setelah hukum ashl.

Tujuh syarat 'illat yang dipaparkan di atas merupakan syaratsyarat yang disepakati oleh ulama ushul baik klasik maupun kontemporer (Sarwat, 2019).

\section{Syarat-syarat Pengqiyas}

Imam asy-Syâfi'î mensyaratkan bagi pengqiyas atau orang yang melakukan qiyas harus memenuhi persyaratan-persyaratan berikut (asy Syâfi'î, 1940):

1. Mengetahui bahasa Arab. Karena agama Islam ini datang dengan bahasa Arab, setiap mujtahid haruslah mengetahui bahasa ini.

2. Mengetahui ketentuan-ketentuan dalam al-Qur'an, kewajibankewajiban dan disiplin etisnya, ayatayat yang me-nasakh-kan dan yang di-mansukh-kan, yang 'am (umum) dan yang khas (khusus), tujuan ditetapkannya suatu hukum (maqâshid at-tasyrî́') dan sebagainya. Ayat-ayat yang mempunyai banyak arti, hendaklah ditafsirkan dengan al-hadits, jika tidak ditemukan alHadits, hendaklah dengan ijmấ dan jika tidak dimungkinkan hendaklah dengan qiyas. Oleh karena itu ia harus:

a. Mengetahui al-hadits, pendapat sahabat, ijmâ' ulama, perbedaan pendapat mereka dan qiyas.

b. Memiliki akal sehat dan pikiran baik, mampu membedakan buktibukti yang hampir sama dan tidak terburu-buru dalam mengemukakan pendapat.

c. Bersikap terbuka sehingga bersedia mendengarkan pendapat orang lain yang berbeda dengan pendapatnya. Dalam hubungan ini ia harus mengerahkan segala kemampuannya dan waspada terhadap suara nuraninya, sehingga ia mengetahui pendapat mana yang harus dipegang dan mana yang harus ditinggalkannya, tidak berkeras kepala dengan pendapatnya sendiri dan tidak apriori terhadap pendapat orang lain sehingga atas kehendak Allah dia mengetahui akan kelebihan dan kekurangan masing-masing.

\section{6. 'Illat dan Masâlik al-'Illat}

'Illat secara bahasa berarti penyakit, sebab atau alasan (Munawwir, 1997; Yunus, 1973). 'Illat pula diartikan sesuatu yang keberadaannya pada suatu hal merubah kondisi pada hal tersebut (al Jurjânî, t.t.; Manzhûr, 1981). Penyakit itu disebut 'illat, karena 
dengan adanya penyakit, maka tubuh manusia berubah dari keadaan sehat menjadi sakit. (Haroen, 1996)

Sedangkan secara istilah menurut al Ghazâlî, 'illat adalah sifat yang berpengaruh kepada hukum, bukan karena dirinya melainkan dengan ketetapan Allah. (al Ghazâlî, 1993) Sementara itu al Âmidî, mendefinisikan 'illat sebagai sifat yang melahirkan hukum yang dilengkapi dengan hikmah yang shalih yang disengaja oleh syari' (Allah SWT) dalam pensyariatan hukum. (al Âmidî, 1982) Ibnu Qayyim al-Jauziyyah mengungkapkan 'illat adalah suatu sifat atau keadaan yang relevan dengan hukum. (al Jauziyyah, 1968a) Muhammad Abû Zahrah berpendapat 'illat adalah suatu sifat atau keadaan yang jelas, pasti lagi serasi sebagai (dasar) penetapan hukum. (Zahrah, 1973) Sedangkan dalam uraian 'Abdul Wahhâb Khallâf, 'illat adalah sesuatu yang jelas yang dijadikan oleh syari' sebagai tambatan hukum yang tujuannya adalah untuk merealisasi hikmah yang terkandung dalam ketetapan hukum tersebut. (Khallâf, 1993)

Ada beragam nama yang dikenal sebagai penyebutan yang merujuk kepada 'illat. Berbagai macam istilah penyebutan tersebut dilatarbelakangi adanya ketidaksepakatan terhadap pemaknaan 'illat dikalangan para ulama. Mazhab-mazhab fikih awal, Iraq maupun Madinah menggunakan sebutan mencari penghubung atau perantara umum antara kasus asal dengan kasus cabang yang membenarkan penggunaan qiyas, tetapi mereka tidak menggunakan istilah 'illat, istilah yang belakangan digunakan oleh para ahli fikih. Sebagaimana unsur umum bagi kasus asal dan kasus cabang yang menjadi dasar penalaran qiyas disebut ma'na oleh asy-Syâfi' î. Nama-nama lain yang menjadi istilah penyebutan terhadap 'illat pada periode pertengahan antara lain ma'na (ide, dasar), sabab (sebab), amârah (tanda), dâ' (motif), mustad'î (faktor yang menuntut), bâ'its (pendorong, motif), hâmil (pembawa pesan), manâth (yang menjadi pautan, dasar), dalîl (yang menjadi petunjuk, indikasi), muqtadhî (yang menuntut), mîjib (yang mengharuskan) dan muatsir (yang mempengaruhi). 'illat juga disebut dengan jâmi'(penghubung), muarrif (penanda) dan jalîb (yang menarik hukum). (Hamid, 2009)

Kaidah ushul terkait 'illat yang memiliki posisi penting dalam penalaran qiyas yakni (al Asmarî, 2000; al Bâqistânî, 2002; an Nadawî, 1999):

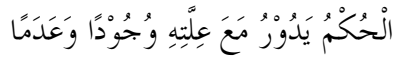

"Hukum berputar (berlaku) bersama ada atau tidak adanya 'illat."

Berkaitan kaidah ushul di atas, Ibnu Qayyim menyatakan bahwa apabila syara' mengantungkan hukum dengan 'illat (sebab hukum), hukum tersebut akan hilang dengan hilangnya 'illat tersebut. (al Jauziyyah, 1968b) Ibnu Taimiyah menyatakan bahwa jika 'illat hilang maka hukum yang digantungkan terhadap 'illat tersebut juga hilang, tetapi bisa juga hukum tersebut tidak hilang jika terdapat 'illat yang lain. Jika hukumnya tidak hilang padahal tidak ada hukum yang lain, maka itu menunjukkan bahwa 'illat tersebut tidak berpengaruh dan batal. (al Harânî, 1995) 
'Illat berdasarkan ada atau tidak terdapatnya nash terbagi menjadi 'illat manshûshah dan 'illat mustanbathah. 'Illat manshîshah atau disebut juga 'illat naqliyah adalah 'illat yang disebutkan lafadznya di dalam nash, baik lafadz itu bersifat sharih maupun zhahir. Lafadz yang bersifat sharih berarti lafadz tersebut pasti sebuah 'illat dan lafadz yang bersifat zhahir berarti lafadz yang berpeluang menjadi 'illat namun masih ada kemungkinan ditafsirkan bukan sebuah 'illat. Sedangkan 'illat mustanbathah adalah 'illat yang tidak disebutkan lafadz yang menunjukkan adanya 'illat secara nyata di dalam nash, namun keberadaannya didapat melalui hasil istinbath para ulama. (Sarwat, 2019)

Eksistensi 'illat hukum begitu urgen dan menentukan untuk bisa diterapkannya qiyas. Suatu simpulan tidak bisa ditarik dengan penalaran qiyas, apabila tidak ada kesamaan antara 'illat pada kasus yang satu yang menjadi ashl dengan kasus yang lainnya yang menjadi far'. (Azhari, 2014) Penyelidikan 'illat dalam kajian ushul fikih disebut dengan masâlik al'Illat. Masâlik al-'Illat adalah metodemetode yang digunakan untuk mengetahui 'illat (sebab hukum) dalam ashl (perkara pokok). Untuk menentukan 'illat dari beberapa sifat itu haruslah melalui metode-metode yang telah dirumuskan para ulama ushul yang memang telah melalui pengkajian yang mendalam dan tidak bertentangan dengan prinsip-prinsip ushul fikih.

Ada perbedaan di antara para ulama dalam perumusan, pengklasifikasian maupun penamaan pada metode-metode dalam masâlik al-'Illat. As-Sarakhsî menyebutkan tiga metode pencarian 'illat yakni an-nash, fahwa annash dan al-istidlal bi hukmi an-nash (as Sarakhsî, 1953), Tâjuddîn as-Subkî merumuskan sepuluh metode yakni alijmâ', an-nash ash-sharîh, al-îmâ', as-sabr wa at-taqsîm, al-munâsabah wa al-ikhâlah, asy-syabah, ad-daurân, ath-thardh, tanqîh al-manâth dan ilghâ' al-Fâriq (as Subkî, 2003), Wahbah az-Zuhailî merumuskan sembilan metode yakni an-nash, al-ijmâ', al-îmâ', as-sabr wa at-taqsîm, al-munâsabah, asy-syibh, ath-thard, ad-daurân dan tanqîh al-manâth (W. az Zuhailî, 1986), Khudharî Bik merumuskan empat metode yakni al-ijmâ', an-nash, as-sabr wa at-taqsîm dan ad-daurân (Bik, 1969), lalu Abû Zahrah merumuskan tiga metode yakni an-nash, al-ijmấ dan almunâsabah yang di dalamnya terdapat tanqîh al-manâth, takhrîj al-manâth dan tahqîq al-manâth. (Zahrah, 1973) Pada bagian ini akan dipaparkan lima masâlik al-'Illat sebagai berikut:

1. an-Nash

Ketika terdapat nash baik alQur'an maupun hadits yang secara eksplisit dan jelas menyebut sifat tertentu sebagai 'illat suatu hukum maka 'illat tersebut merupakan 'illat yang tersurat dalam nash yang disebut nash sharîh. Selain itu ada pula ayat al-Qur'an ataupun hadits yang tidak menampilkan 'illat suatu hukum secara tersurat, melainkan secara tersirat atau implisit melalui indikasi-indikasi atau isyarat terhadap 'illat tersebut yang diistilahkan nash zhahir. Metode pencarian 'illat dengan menggali 
pada isyarat-isyarat yang tertuang di dalam nash yang mengindikasikan kepada 'illat disebut pula dengan metode al-îmâ:

2. al-Ijmấ

Ketetapan ijmấ merupakan sebuah metode dalam pencarian 'illat. Dalam eksistensinya pada masâlik al-'Illat, ada yang menempatkan ijmâ' pada posisi pertama, ada pula yang menempatkan ijmấ pada posisi kedua setelah nash dalam perspektif masâlik al-'Illat. Diluar masalah perbedaan pada persoalan eksistensi ijmâ' dalam masâlik al-'Illat, ijmâ' tetap menjadi landasan yang kuat untuk dijadikan sandaran pada pencarian 'illat.

3. as-Sabr wa at-Taqsîm

As-sabr adalah penyelidikan seorang mujtahid untuk menentukan satu dari sekian banyak sifat yang terkandung dalam ashl yang berhasil diinventarisir dengan cara membuang semua sifat yang dinilai tidak layak dijadikan 'illat dengan berpedoman pada dalil-dalil yang bisa menguatkan. Sedangkan at- taqsîm adalah pengakomodiran seorang mujtahid terhadap semua sifat yang terkandung dalam ashl yang disinyalir pantas dan layak untuk ditetapkan sebagai 'illat dari hukum ashl.

As-sabr wa at- taqsîm dalam kajian masâlik al-'Illat adalah membatasi beberapa sifat yang termuat pada ashl dan memungkinkan menjadi 'illat. Kemudian dilakukan pengujian atas sifat-sifat tersebut dengan membatalkan sifat-sifat yang tidak layak menjadi 'illat hingga mengerucut pada sifat yang tersisa. Dari penelitian tersebut akhirnya dapat diketahui bahwa yang tersisa itulah yang layak menjadi 'illat. (Sarwat, 2019) Ada perbedaan di kalangan para ulama ushul fikih terkait penamaan metode ini. Sebagian ulama yang salah satu di antaranya adalah as-Subki menamakan metode ini as-sabr wa at- taqsîm berpijak pada pendapat bahwa tindakan terpenting dari metode ini adalah pada saat upaya mujtahid dalam menganalisis sifat-sifat yang ada (as-sabr), maka dari itu dinamakanlah metode ini as-sabr wa at- taqsîm. Berbeda halnya dengan alIsnawi yang menamakan at- taqsîm wa as-sabr dengan alasan bahwa langkah awal penemuan 'illat dengan metode ini adalah menginventarisir sifat-sifat (at- taqsîm). Lalu al-Baidhawi justru lebih sederhana dengan menamakannya at- taqsîm dan ada pula yang menamakan as-sabr tanpa disertai attaqsîm. (al 'Aththâr, 2016; al Mahallî, 2005)

4. al-Munâsabah

al-munâsabah dalam kajian masâlik al-'Illat adalah metode pencarian 'illat dengan menggunakan standar munâsabah (keserasian) antara 'illat dan hukum melalui proses tanqîh al-manâth, takhrîj almanâth dan tahqî̀ al-manâth. Tanqîh al-manâth adalah melakukan proses peringkasan sifat yang menjadi dasar digantungkannya hukum atasnya, dimana sifat-sifat itu disebutkan atau tertuang di dalam teks nash yang menjadi ashl. Lalu takhrîj al-manâth adalah menentukan 
'illat dari sifat-sifat yang ada pada hukum berdasarkan faktor keserasian atau keselarasan antara 'illat dan hukum disertai adanya kebersamaan antara keduanya. Sedangkan tahqîq al-manâth mengukuhkan 'illat dan menerapkan 'illat yang telah ditentukan tersebut pada suatu hukum ashl atas sebuah kasus

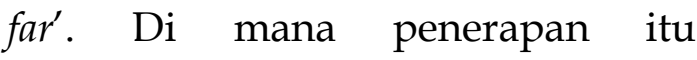
didasarkan atas adanya keserasian antara 'illat dan hukum far' sebagaimana pada ashl. (Sarwat, 2019) Tanqîh al-Manâth berkaitan dengan 'illat manshîshah, lalu takhrîj al-manâth berkaitan dengan 'illat mustanbathah, sedangkan tahqîq almanâth berkaitan dengan 'illat manshûshah maupun mustanbathah (Sahroni, 2017).

5. ad-Daurân

ad-Daurân adalah menetapkan 'illat dengan melihat perputaran hukum berdasarkan sifatnya. Ketentuannya adalah apabila sifat tersebut ada, maka hukum akan ada dan sebaliknya apabila sifat tidak ada maka hukum tidak ada. Dengan begitu dapat dipastikan bahwa sifat tersebut adalah 'illat (Sarwat, 2019).

\section{PENEMUAN HUKUM DENGAN QIYAS DALAM EPISTEMOLOGI HUKUM ISLAM: SUATU UPAYA PENGEMBALIAN MASALAH KEPADA AL-QUR'AN DAN SUNNAH SERTA MEMELIHARA KEMASLAHATAN}

Epistemologi Hukum Islam pada awalnya memiliki dua corak yakni normatif-tekstual dan rasional-konteks- tual. (Musonnif, 2019) Kehadiran penalaran qiyas ini menjadi metode penengah antara ahl al-hadîts dan ahl al$r a^{\prime} y$. (H. Rohman, 2018) Ontologi (hakikat) hukum Islam itu adalah interrelasi antara teks, nalar dan realita. Maka kedudukan qiyas dalam epsitemologi hukum Islam adalah kombinasi dan integrasi antara teks dan nalar. Qiyas merupakan suatu cara penggunaan $r a^{\prime} y$ untuk menggali hukum syara' dalam hal-hal yang nash alQur'an dan sunnah tidak menetapkan hukumnya secara pasti (qoth'i). Walaupun qiyas tidak menggunakan nash secara langsung, tetapi karena merujuk kepada nash, maka dapat dikatakan bahwa qiyas tetap mengembalikan pemecahan masalah kepada nash, namun tidak secara langsung yakni pada merujuk kepada ashl (kasus hukum yang tertuang pada nash) yang dijadikan sandaran $f a^{\prime} r$ (kasus hukum yang tidak tertuang pada nash) yang dihubungkan dengan kesamaan 'illat (sebab hukum). (Surono, 2012) Maka demikian, dengan qiyas problematika umat yang terwujud pada kasus-kasus hukum baru yang belum ter-cover oleh alQur'an, sunnah dan ijma' akan mendapatkan titik terang dalam mewujudkan kemaslahatan umat. Sehingga jika dikatakan qiyas adalah pembatas hukum maka ini kuranglah tepat mengingat apa yang ada dalam sumber hukum Islam terutama al-Qur'an banyak yang bersifat universal, umum dan global. (Kholiq, 2014)

Maka dalam pengaplikasian metode qiyas, permasalahan tetap dikembalikan kepada teks syariah yakni al-Qur'an dan hadits dengan bertumpu pada illat (sebab hukum) maka far' yang merupakan perkara cabang/kasus baru yang tidak 
190

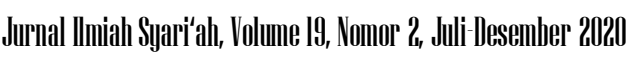

ditemukan hukumnya secara langsung dalam nash disandarkan kepada ashl yang merupakan perkara pokok/kasus hukum yang telah ada ketetapan hukumnya di dalam nash dengan garis yang menyatukan diantara keduanya adalah 'illat yang menjadikan hukm al-ashl berlaku pula pada far'. Nalar dalam hal ini digunakan untuk menemukan kesamaan 'illat antara far' dengan ashl sehingga dapat dihubungkan antara keduanya dan diberlakukan hukm al-ashl padanya far' tersebut, serta juga digunakan untuk menelusuri dan mengeluarkan 'illat dari dalam nash baik ketetapan dalam ayat ahkam maupun hadits ahkam, karena 'illat dapat berbentuk 'illat manshushah (tertuang dalam nash) dan 'illat mustanbathah (tidak tertuang di dalam nash/hasil istinbath ulama).

Tujuan Allah SWT mensyariatkan hukumnya adalah untuk memelihara kemaslahatan manusia sekaligus untuk menghindari mafsadat, baik di dunia maupun di akhirat. Tujuan tersebut hendak dicapai melalui taklif yang pelaksanaannya tergantung pada penalaran sumber hukum utama yaitu alQur'an dan sunnah. (Djamil, 1997) Maslahat merupakan aspek yang menjadi tujuan disyariatkannya suatu hukum (maqâshid asy-Syarî'ah). Fathi ad-Dâraynî menyatakan bahwa hukum-hukum tidaklah dibuat untuk hukum itu sendiri melainkan dibuat untuk tujuan kemaslahatan. (ad Dâraynî, 1975) Berkaitan dengan aspek maslahat, al-Izz bin 'Abd as-Salam menyatakan bahwa syariat itu semuanya maslahat baik menolak kejahatan maupun menarik kebaikan. (as Salam, 2001) Dalam hal ini asy-Syâthibî yang dikenal sebagai Bapak maqâshid asySyari'ah dengan karya monumentalnya
Kitab al-Muwâfaqât mengatakan bahwasanya syariat itu ditetapkan bertujuan untuk tegaknya kemaslahatan manusia di dunia dan akhirat. Oleh karena itu, asy Syâthibî menegaskan bahwa kemaslahatan tidak diukur oleh hawa nafsu, karena jika sesuatu itu mengandung kemaslahatan dunia tanpa kemaslahatan akhirat, maka itu bukan maslahat. (asy Syâthibî, 2004) Jadi tolak ukur dari maslahat adalah kembali kepada al-Qur'an dan sunnah sebagai mashâdir al-ahkâm asy-syar'iyyah, tidak hanya disandarkan kepada akal saja, melainkan akal haruslah didasarkan dan diarahkan oleh syariat, bukan diarahkan bebas tanpa arah apalagi dibangun oleh hawa nafsu belaka.

Komprehensifnya ajaran Islam telah menunjukkan syariat Islam sebagai hukum yang mengatur habluminallah dan habluminannâs serta alam sekitar dalam kehidupan dengan muatan ibadah dan muamalah. (al Qaradhâwî, 2006; Syaltût, 1996) Syariat tidak lepas dari mashalat, begitupun sebaliknya maslahat tidak lepas dari syariat.

Kaidah terkait (asy Syinqîthî, 1990; W. az Zuhailî, 1985):<smiles>[As]=[As][As]=[As]</smiles>

"Dimana terwujud kemaslahatan, disana terdapat hukum Allah"

Tujuan disyariatkannya hukum adalah untuk kemaslahatan, maka antara syariat dan maslahat tidak dapat dipisahkan, satu sama lain terhubung dalam bingkai hukum Islam. Karena itu tolak ukur dan pedoman maslahat kembali pada syariat, sesuatu yang tidak bertentangan dengan syariat. Maslahat terwujud dalam dimensi duniawiukhrawi, maka qiyas menjadi cara mewujudkan maslahat tersebut dengan 
pengembalian masalah kepada syariat melalui nash.

Kaidah terkait (Ismâ'îl, 1958):

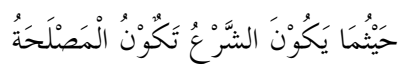

"Dimana hukum syara' dilaksanakan, disana tercipta kemaslahatan."

Menurut al-Ghazâlî maslahat kembali pada penjagaan maqâshid asy-syarî'ah. dan kemaslahatan didapatkan apabila terwujudnya dan terpeliharanya lima unsur pokok, yaitu hifzh ad-din (memelihara agama), hifzh an-nafs (memelihara jiwa), hifzh al-'aql (memelihara akal/pikiran), hifzh an-nasb (memelihara keturunan), dan hifzh al-mâl (memelihara harta) (al Ghazâlî, 1993). Pemeliharaan lima pokok tersebut mempunyai tiga tingkatan sesuai dengan maslahat dan kepentingannya, yakni dharuriyat (primer), hajiyat (sekunder) dan tahsiniyat (tersier).

Pada hakikatnya tidak ada qiyas yang bertentangan dengan nash baik alQur'an maupun sunnah. Apabila ditemukan qiyas yang bertentangan dengan nash, maka hal ini menunjukkan bahwa qiyas tersebut batal atau tidak sah. (al Bâqistânî, 2002). Karena pada dasarnya qiyas tidaklah berdiri sendiri, melainkan tetap kembali kepada nash sebagai sandaran utama. Kaidah terkait berbunyi (Komite Ulama Khilâfah 'Utsmâniyah, t.t.):

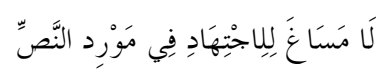

"Tidak ada ijtihad bersamaan dengan nash."

Kaidah ini menunjukkan tidak boleh ijtihad dalam suatu hukum yang memang sudah ada ketetapan pastinya dalam nash. Jika telah ada ketentuan di dalam nash, maka tidak boleh ijtihad kecuali untuk memahami nash tersebut dan dalalahnya. (al Ghuzzî, 1996; M. M. az Zuhailî, 2006)

Ijtihad dimaksimalkan fungsinya sebagai alat penggali hukum pada masa tabi'in, bahkan dipandang sebagai suatu kebutuhan yang harus dilakukan untuk bisa menjawab persoalan-persoalan baru yang belum ada ketetapan hukumnya. (Nofrianti, 2018) Berbedahalnya di masa sahabat, ijtihad belum bisa disebut sebagai alat penggali hukum, oleh karena saat itu di masa Rasulullah SAW masih hidup, setiap persoalan yang dihadapi sahabat dan mereka mengalami kebingungan maupun keragu-raguan akan suatu kasus hukum, maka dapat bertanya langsung kepada Rasulullah SAW untuk meminta jawabannya.

Sedangkan melihat situasi dan kondisi saat ini, dimana derasnya arus perkembangan zaman dan pesatnya kemajuan teknologi serta peralihan dan pergeseran perilaku sosial dalam interaksi yang kompleks, maka mempengaruhi berbagai sektor kehidupan yang pada akhirnya melahirkan kasus-kasus baru yang menjadi persoalan yang dihadapi dan sangat penting untuk mendapatkan status hukum agar memberikan kepastian hukum akan eksistensinya di masyarakat. Maka dengan begitu, ijtihad menduduki posisi yang sentral dalam merespons hal tersebut, agar umat tidak kebingungan dan dilanda rasa keragu-raguan dalam menghadapi persoalan kekinian yang begitu beragam dengan mendapatkan jawaban untuk memecahkan masalah hukum yang terjadi.

Imam Syâfi'î dalam kitab ar-Risâlah menegaskan bahwa tidak seorang pun boleh mengatakan tentang status hukum 
(halal dan haram) suatu barang atau perbuatan kecuali berdasarkan pengetahuan dan pengetahuan hanya dapat diperoleh dari al-Qur'an, sunnah, ijma' atau qiyas. (asy Syâfi'î, 1940) Ijtihad sebagaimana yang dipaparkan Imam asy Syâfi'î pada kitab ar-Risâlah-nya, mengarah pada konsep qiyas. Qiyas dalam kajian Imam asy Syâfi'î pada kitab ar-Risâlah menunjukkan bahwa sumber hukum sekaligus pengetahuan qiyas adalah al-Qur'an dan sunnah yang dalam istilah teknis yang digunakan Imam asy Syâfi'î dalam ar-Risâlah adalah al-khabar almutaqaddam. Istilah ini yang berikutnya dalam kajian ushul fikih lebih populer dengan sebutan ashl. (Mz, 2009)

Lalu eksistensi dan posisi qiyas dalam hukum Islam pula disebutkan Imam Syâfi'î dalam al-Umm ketika menjelaskan tentang tingkatan ilmu. Imam Syâfi'î memetakan ilmu dengan menyatakan bahwa ilmu itu bertingkattingkat. Tingkat pertama, yakni al-Qur'an dan sunnah; kedua yakni ijmâ' terhadap sesuatu yang tidak terdapat dalam alQur'an dan Sunnah; ketiga yakni qaul sebagian sahabat tanpa ada yang menyangkalnya; keempat adalah pendapat sahabat Nabi SAW yang antara satu dengan yang lainnya ada perselisihan/berbeda-beda (ikhtilâf); dan kelima yakni qiyas terhadap salah satu dalil-dalil di atas. Selama keterangan suatu perkara terdapat dalam al-Qur'an dan sunnah, tidak diperlukan bersandar pada dalil lain, sebab ilmu itu diambil dari sumber yang paling tinggi. (asy Syâfi'î, 1990)

Berkaitan sumber hukum Islam yakni al-Qur'an dan sunnah yang menjadi pengetahuan dan rujukan dalam penalaran qiyas, Allah SWT berfirman dalam QS. an-Nisâ': 59

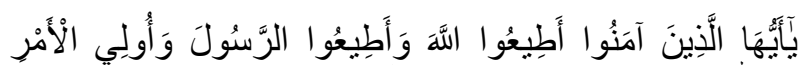

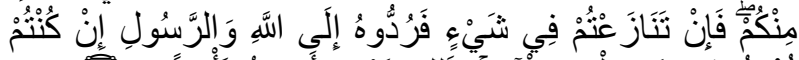

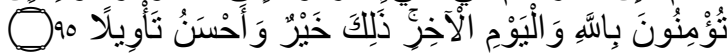
"Hai orang-orang yang beriman, taatilah Allah dan taatilah Rasul (Nya), dan ulil amri di antara kamu. kemudian jika kamu berlainan Pendapat tentang sesuatu, Maka kembalikanlah ia kepada Allah (Al Quran) dan Rasul (sunnahnya), jika kamu benarbenar beriman kepada Allah dan hari kemudian. yang demikian itu lebih utama (bagimu) dan lebih baik akibatnya."(QS. anNisa' [4]: 59)

Kemudian terdapat beberapa hadits terkait dengan mashâdir al-ahkâm assyar'iyyah, yakni:

Hadits riwayat Mâlik dalam alMuwaththa' (al Madanî, 1985):

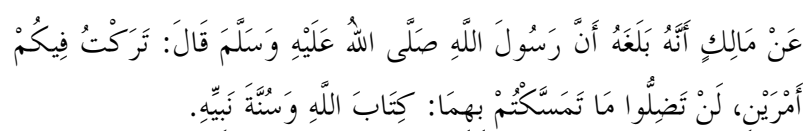

Dari Malik telah sampai kepadanya Sesungguhnya Rasulullah SAW bersabda: "Telah aku tinggalkan untuk kalian, dua perkara yang kalian tidak akan sesat selama kalian berpegang teguh dengan keduanya; Kitabullah dan Sunnah Nabi-Nya."

Kemudan hadits riwayat al-Hâkim dalam al-Mustadrak 'alâ ash-Shahîhain (an Naisâbûrî, 1990):

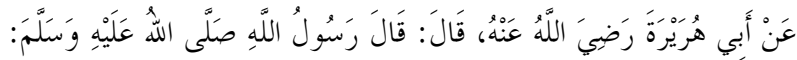

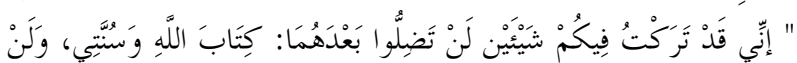

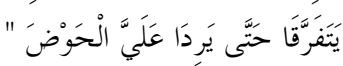

Dari Abu Hurairah RA, ia berkata: Rasulullah SAW bersabda: "Sesungguhnya aku telah meninggalkan untuk kalian dua pedoman yang tidak akan membuat kalian tersesat sesudahnya, (yaitu) Kitab Allah dan Sunnahku, keduanya tidak akan berpisah hingga sampai di telaga."

Lalu hadits riwayat at-Tirmidzî dalam Sunan at-Tirmidzî (at Tirmidzî, 1998b): 


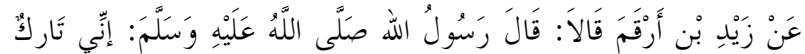

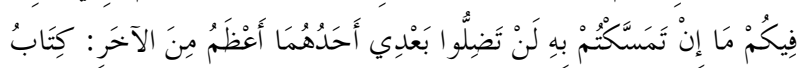

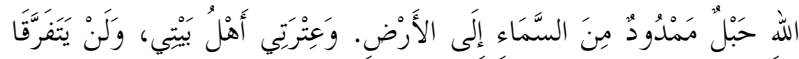

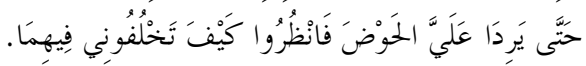

Dari Zaid bin Arqam, ia berkata: Rasulullah SAW bersabda: "Sesungguhnya aku telah meninggalkan untuk kalian sesuatu yang sekiranya kalian berpegang teguh kepadanya, niscaya kalian tidak akan tersesat sepeninggalku, salah satu dari keduanya itu lebih agung dari yang lain, yaitu; kitabullah adalah tali yang Allah bentangkan dari langit ke bumi, dan itrahku (keturunanku) dari ahli baitku, dan keduanya tidak akan berpisah hingga keduanya datang menemuiku di telaga, oleh karena itu perhatikanlah, apa yang kalian perbuat terhadap keduanya sesudahku."

Eksistensi penalaran qiyas dapat disebut sebagai pemelihara maslahat dalam hukum cabang (far'). Menurut Muhammad Sa'îd Ramadhân al Bûthî, qiyas merupakan upaya untuk memelihara maslahat pada far' yang didasarkan pada persamaan 'illat yang ada pada ashl. Qiyas pasti mengandung pemeliharaan maslahat, namun tidak setiap pemeliharaan maslahat berarti qiyas. (al Bûthî, 1973) Oleh karena itu, pada dasarnya upaya pengqiyasan dalam proses penggalian dan penemuan hukum Islam merupaya upaya untuk mencapai kemaslahatan, karena penalaran qiyas tidaklah berdiri sendiri, melainkan tetap kembali kepada mashâdir al-ahkâm asysyar'iyyah yakni al-Qur'an dan sunnah sebagai pegangan dan tumpuan utama dengan cara menghubungkan dan menyandarkan far' kepada ashl yang terdapat di dalam nash melalui kesamaan 'illat yang memang didasarkan pada kajian yang mendalam untuk dapat menarik garis penghubung tersebut

Untuk menyelesaikan kasus-kasus yang tidak diatur secara tersurat dan jelas di dalam nash al-Qur'an maupun sunnah, maka dalam kajian ushul fikih, sebuah upaya yang dapat diaplikasikan sebagai ikhtiar penyelesaiannya dengan jalan mengembalikan persoalan tersebut kepada al-Qur'an dan sunnah itu sendiri. Pengembalian kepada sumber hukum utama tersebut dapat dilakukan melalui dua cara, yaitu dengan perluasan makna lafaz melalui jalan qiyas dan tujuan disyariatkannya hukum (Maqâshid asySyarî'ah). (Riyadi, 2016)

Tipologi metode penemuan hukum dalam epistemologi hukum Islam pada literatur filsafat hukum Islam maupun kajian ushul fikih kontemporer secara garis besar dibagi menjadi tiga metode, yakni lughawiyah, ta'liliyah dan itishlahiyah (Al Yasa, 2016), atau adapula yang membaginya menjadi ijtihad bayani, qiyasi dan ta'lili. (Mazkur, 1984) Metode lughawiyah/bayani dapat disebut pula dengan istilah metode linguistik atau interpretasi literal, metode qiyasi/ta'lili dengan sebutan metode kausasi dan metode istishlahi dengan sebutan metode teleologis. Metode qiyas yang dikaji dalam tulisan ini masuk dalam kategori metode ta'lili atau kausasi. Metode ta'lili atau kausasi diartikan sebagai perluasan berlakunya hukum suatu kasus yang ditegaskan di dalam nash kepada kasus baru berdasarkan 'illat atau causa legis yang digali dari kasus nash kemudian diterapkan kepada kasus baru tersebut. Metode kausasi ini berupaya melakukan penggalian causa legis dari hukum kasus pararel untuk diterapkan kepada kasus 
serupa yang baru. Maka apa yang dilakukan ahli hukum di sini adalah binâ al-hukm 'alâ al-illah atau pendasaran hukum kepada causa legis Jika tidak ada kasus paralel, maka pendasaran hukum kepada causa legis tidak dapat dilakukan. Oleh karena itu penemuan hukum dapat dilakukan dengan ta'lîl al-ahkâm bi maqâshid asy-Syarî'ah, atau dengan kata lain pendasaran hukum kepada causa finalis hukum, yaitu maqâshid asy-Syarî'ah. (Haris, 2012)

QS. an-Nisâ' (4): 59 menunjukkan jika ada perselisihan pendapat diantara ulama tentang hukum suatu masalah, maka jalan keluarnya dengan mengembalikannya kepada al-Qur'an dan sunnah, maka qiyas menjadi suatu upaya dalam pengembalian tersebut. (Kholiq, 2014) Dikarenakan kasus baru yang menjadi masalah cabang ( $\left.f a r^{\prime}\right)$ tidak diatur dan belum ada status hukumnya dalam nash baik al-Qur'an maupun sunnah, maka dikembalikan dan dihubungkan kepada masalah pokok (ashl) yang telah ada ketentuan hukumnya di dalam nash melalui persamaan sebab hukum ('illat). Kesamaan 'illat antara perkara yang tidak ada nashnya dengan perkara yang ada nashnya menyebabkan adanya kesatuan hukum. (Sakirman, 2018) Sehingga sebagaimana ketentuan hukum pada ashl, seperti itulah diberlakukan pada far'-nya.

\section{METODE QIYAS DAN FORMULASI RECHTSVENDING DALAM TEORI HUKUM KONVENSIONAL}

Jika dikaitkan dengan formulasi rechtsvending (penemuan hukum) dalam teori hukum konvensional mengacu pada tipologi metode interpretasi dan konstruksi hukum, maka qiyas secara metodologis masuk dalam metode konstruksi hukum. Dalam perspektif formulasi rechtsvending oleh seorang hakim dalam teori hukum konvensional ini, metode interpretasi terbagi lagi menjadi interpretasi gramatikal, historis, sistematis, teleologis, komparatif, futuristik, restriktif, ekstensif, autentik, interdisipliner dan multidisipliner. Sedangkan metode konstruksi hukum meliputi argumentum per analogium, argumentum a contrario dan penyempitan atau pengkongkretan hukum. (Rifai, 2010)

Sebagaimana telah disebutkan sebelumnya, qiyas dalam kajian ushul fikih, jika dikaitkan dengan formulasi rechvending dalam teori hukum konvensional secara metodologis termasuk dalam metode konstruksi hukum dan lebih spesifik lagi dalam kategori metode konstruksi hukum, qiyas secara alur berpikir mirip seperti metode argumentum per analogium, karena samahalnya dengan qiyas, alur berpikir metode argumentum per analogium berporos pada penganalogian yakni menyamakan perkara hukum yang yang tidak ada ketetapannya dengan perkara hukum yang ada ketetapannya karena ada kesamaan yang menghubungkan diantara keduanya. Dengan begitu metode ini beranjak dari pendasaran hukum pada causa legis yang berperan dalam proses penganalogian.

Kontruksi hukum terjadi apabila tidak ditemukan ketentuan undangundang yang secara langsung dapat diterapkan pada masalah hukum yang dihadapi, atau dalam hal peraturannya tidak ada, jadi terdapat kekosongan hukum (recht vacuum) atau kekosongan undang-undang (wet vacuum). (Muwahid, 2017) Lalu metode argumentum per 
analogium (analogi) sebagai bagian dari metode konstruksi hukum merupakan metode penemuan hukum dengan cara hakim mencari esensi yang lebih umum dari sebuah peristiwa hukum atau perbuatan hukum baik yang telah diatur oleh undang-undang maupun yang belum ada peraturannya. Dengan metode analogi, peristiwa yang serupa atau sejenis yang diatur dalam undang-undang diperlakukan sama. Metode penemuan hukum dengan analogi terjadi dengan mencari peraturan umum dari peraturan khusus, untuk digunakan menggali asasasas hukum yang ada di dalamnya. Dengan penemuan hukum melalui metode analogi ini, sebuah peraturan yang bersifat khusus dijadikan umum yang tidak tertulis dalam sebuah undangundang. Dari peraturan umum tersebut, disimpulkan peristiwa-peristiwa yang khusus. Suatu peraturan perundangundangan diterapkan terhadap suatu peristiwa tertentu yang tidak diatur dalam undang-undang tersebut, akan tetapi peristiwa itu mirip atau serupa dengan peristiwa yang diatur dalam sebuah undang-undang. (Mertokusumo, 1996)

Metode konstruksi hukum melalui analogi ini memberi pemahaman pada suatu peraturan hukum dengan pemaknaan yang diperluas melalui penyamaan pada kata-kata dalam peraturan tersebut sesuai dengan asas hukumnya sehingga suatu peristiwa yang sebenarnya tidak dimasukkan, kemudian dianggap sesuai dengan bunyi peraturan tersebut. (Hamidi, 2011; Mertokusumo, 1996)

Secara metodologis, memang konstruksi berpikir qiyas sebagai istinbath alhukm dalam teori hukum Islam memiliki alur berpikir yang serupa dengan argumentum per analogium sebagai formulasi rechtsvending dalam teori hukum konvensional. Keduanya samasama dibangun dengan titik tolak penganalogian pada kasus hukum yang tidak diatur dengan kasus hukum yang telah diatur dengan berpijak pada kesamaan causa legis. Namun lebih jauh secara substantif, terdapat perbedaan pada posisi penggunaan dan sandaran. Qiyas digunakan untuk merespon muamalah yang terus berkembang melahirkan persoalan dan kasus hukum baru, lalu digunakan untuk menemukan hukum terkait sah-bathil maupun halalharam dalam hukum Islam karena nash tidak mengatur secara langsung suatu kasus hukum dan sandarannya kembali pada al-Qur'an dan sunnah serta hukum yang digali adalah nash baik berupa ayat ahkam maupun hadits ahkam, sedangkan argumentum per analogium merupakan salah satu jenis konstruksi hukum yang sering digunakan dalam perkara perdata, lalu digunakan seorang hakim untuk menemukan hukum karena undangundang yang mengatur akan peristiwa kongkrit tidak ada atau tidak ditemukan, maka dalam hal ini penegak hukum (hakim) haruslah mencari, menggali, mengkaji dan menemukan hukumnya (rechtsvending) dan sandarannya kembali pada undang-undang serta hukum yang digali adalah undang-undang.

Dalam perbincangan tentang argumenttum per analogium ini, apabila menggunakan analogi dengan baik dan tepat sasaran dimungkinkan untuk memecahkan persoalan baru dengan suatu peraturan yang dapat ditempatkan dalam suatu hubungan yang erat dengan peraturan-peraturan yang telah diadakan. 
Dengan demikian dianggap bahwa hukum merupakan suatu susunan asasasas yang sangat kokoh dan setiap usaha yang dilakukan untuk membuat hal itu tetap demikian. Maka posisi qiyas pula sebagaimana argumentum per analogium, eksistensinya mengokohkan aturan yang berasal dari sumber hukum atau mashâdir al-ahkâm asy-syar'iyyah dengan penggalian hukum dan pengembalian setiap masalah tidak lepas dari nash, sebab pengqiyasan tidak dapat dilakukan jika tidak ada ashl (perkara pokok) yang berasal dari nash tempat menyandarkan far' (perkara cabang) berupa kasus baru yang memerlukan status hukum.

Menurut Gustav Radbruch sebagaimana disebut Achmad Ali, dalam penegakan hukum terdapat tiga unsur yang dinamakan nilai dasar hukum yang harus selalu diperhatikan untuk mewujudkan hakikat dari fungsi dan tujuan itu sendiri, yaitu: kepastian hukum (rechtssicherheit), kemanfaatan (zweckmassigkeit) dan keadilan (gerechtgkeit) (Ali, 1996). Pengaplikasian argumentum per analogium tidak boleh lepas dari tiga unsur nilai dasar hukum ini, karena keberadaanya dalam upaya penemuan hukum haruslah merepresentasikan kepastian hukum, kemanfaatan dan keadilan.

Sebagaimana disebutkan dalam pembahasan poin sebelumnya, bahwa eksistensi dan aplikasi qiyas tidak lepas dari memelihara kemaslahatan, sebab qiyas merupakan upaya untuk memelihara maslahat pada far' yang didasarkan pada persamaan 'illat yang ada pada ashl. (al Bûthî, 1973) Dengan pemeliharaan maslahat sebagai bagian dari qiyas, maka jika dikaitkan dengan tiga unsur yang dinamakan nilai dasar hukum seperti disebut Gustav Radbruch berupa kepastian hukum, kemanfaatan dan keadilan, hal tersebut pula menjadi pilar yang tercermin dalam kemaslahatan pada pengaplikasian qiyas dalan penemuan hukum. Hal tersebut pula dapat dirasakan pada eksistensi argumentum per analogium sebagai formulasi rechtsvending, sebab pengaplikasinnya merupakan wujud konstruksi hukum karena ada kekosongan hukum yang pada akhirnya dapat memberikan kepastian hukum. Namun yang membedakan, kemaslahatan dalam argumentum per analogium hanya berdimensi duniawi dan kemaslahatan yang dimaksud berdasar logika/akal pikiran/penalaran seorang hakim dalam memahami undang-undang, sedangkan kemaslahatan yang berada pada pengaplikasian qiyas bernuansa religiusitas Islam, kembali lagi pada teks syariat yakni al-Qur'an dan sunnah, sebab tolak ukur kemaslahatan bukanlah sekedar akal pikiran atau bahkan hawa nafsu, melainkan kembali ke syariat, sebab tujuan pensyariatan suatu hukum adalah maslahat dan suatu kaidah mengatakan "apabila hukum syara' diterapkan, maka pastilah tercipta kemaslahatan." Kaidah ini menegaskan bahwa tolak ukur maslahat itu berdimensi duniawi-ukhrawi yang titik tolaknya adalah syariat yang tertuang di dalam nash.

\section{PENUTUP}

Formulasi rechtsvinding (penemuan hukum) dengan penalaran analogis dalam epistemologi hukum Islam didasarkan pada perluasan berlakunya hukum suatu kasus yang ditegaskan di dalam nash kepada kasus baru berlandaskan causa legis ('illat) yang digali dari kasus nash yang selanjutnya 
diterapkan kepada kasus baru tersebut. dalam hal ini apa yang dilakukan dalam penemuan hukum adalah pendasaran hukum kepada causa legis. Alur berpikir qiyas sebagai penggunaan $r a^{\prime} y$ terhadap mashâdir al-ahkâm asy-syar'iyyah secara metodologis dibangun atas empat unsur penting yang harus ada dan menjadi pola pembentukan hukumnya yakni ashl, far', hukm al-ashl dan 'illat. Hukum dapat ditemukan ketika ada kesamaan causa legis ('illat) antara perkara pokok (far') dengan perkara cabang (ashl) sehingga ketetapan hukum dalam kasus pada nash (hukm alashl) dapat diberlakukan pada kasus baru ( $\left.f r^{\prime}\right)$. Aplikasi qiyas tidak lepas dari memelihara kemaslahatan, sebab qiyas merupakan upaya untuk memelihara maslahat pada far' yang didasarkan pada persamaan 'illat yang ada pada ashl.

Qiyas dalam perbincangan formulasi rechtsvinding teori hukum konvensional, secara metodologis memiliki kesamaan alur berpikir dengan argumentum per analogium yang merupakan bagian dari metode konstruksi hukum. Penemuan hukum antara qiyas dan argumentum per analogium sama-sama beranjak dari proses penganalogian kasus hukum yang ada ketetapannya dengan kasus hukum yang tidak ada ketetapannya karena ada kesamaan yang menghubungkan di antara keduanya. Namun pengaplikasian qiyas bermuara pada al-Qur'an dan sunnah, sedangkan argumentum per analogium pada undang-undang.

\section{DAFTAR PUSTAKA}

ad Dâraynî, F. (1975). Al-Minhâj al-Ushûliyyah fî Ijtihâd bî ar-Ra'yi fî at-Tasyrî́. Damaskus: Dâr al-Kutub al-Hadîts. ad Dârimî, A. M. 'Abdullah bin 'Abdurrahman bin al-F. bin B. bin'Abdusshamad. (2000). Sunan adDârimî (Vol. 1). Arab Saudi: Dâr alMughnî.

al Âmidî, A. al H. 'Alî bin A. 'Alî bin M. bin S. (1982). Al-Ihkâm fì Ushûl al-Ahkâm (Vol. 3). Beirut: al-Maktab al-Islâmî.

al Asmarî, S. bin M. bin H. (2000). Majmû'ah al-Fawâid al-Bahiyyah 'Alâ Manzhûmah al-Qawấ'id al-Fighiyyah. Riyadh: Dâr ash-Shamî'̂̀.

al 'Aththâr, H. bin M. (2016). Hâsyiyah al'Aththâr 'alâ Syarah Jalâluddîn al-Mahallî "alâ Jam" al-Jawâmi.' Beirut: Dâr alKutub al-'Ilmiyah.

al Bâqistânî, Z. bin G. Q. (2002). Min Ushûl alFigh 'Alâ Manhaj Ahl al-Hadîts. Marokko: Dâr al-Kharâz.

al Bûthî, M. S. R. (1973). Dhawâbith alMashlahah fi asy-Syarî'ah al-Islâmiyyah. Beirut: Muassasah ar-Risâlah.

al Ghazâlî, A. H. M. bin M. (1993). AlMustashfâ min 'Ilm al-Ushûl (Vol. 2). Beirut: Dâr al-Kutub al-'Ilmiyah.

al Ghuzzî, A. al H. M. S. bin A. al B. (1996). AlWajîz fî İdhâh Qawấ'id al-Figh alKulliyyah. Beirut: Muassasah arRisâlah.

al Harânî, A. al Q. A. bin 'Abdul H. bin 'Abdus S. bin T. (1995). Majmû' alFatâwâ (Vol. 17). Madinah: Majma' alMulk Fahd li Thabâ'ah al-Mushhaf asy-Syarîf.

al Jauziyyah, M. bin A. B. bin Q. (1968a). I'lâm al-Muwaqqi'în 'an Rabb al-'âlamîn (Vol. 1). Kairo: Maktabah al-Kulliyât alAzhariyah.

al Jauziyyah, M. bin A. B. bin Q. (1968b). I'lâm al-Muwaqqi'în 'an Rabb al-'âlamîn (Vol. 4). Kairo: Maktabah al-Kulliyât alAzhariyah. 
al Jurjânî, 'Alî bin Muhammad as Sayyid asy Syarîf. (t.t.). Mu'jam at at-Ta'rîfât. Kairo: Dâr al-Fadhîlah.

al Madanî, M. bin A. bin M. bin Â. al A. (1985). Al-Muwaththa' (Vol. 2). Beirut: Dâr Ihyâ' at-Turâts al- Ârab.

al Mahallî, J. M. bin A. (2005). Al-Badr athThâli' fî hall Jam' al-Jawâmi' (Vol. 2). Damaskus: Muassasah ar-Risâlah.

al Qaradhâwî, Y. (2006). Fiqih Maqashid Syariah: Moderasi Islam antara Aliran Tekstual dan Liberal (A. M. Riswanto, Penerj.). Jakarta: Pustaka al-Kautsar.

al Qaradhâwî, Y. (2010). Al-Qawấ'id al-Hâkimah li Figh al-Mu'âmalât. Kairo: Dâr asySyurûq.

Al Yasa, A. B. (2016). Metode Istislahiah, (Pemanfatan Ilmu Pengetahuan dalam Ushul Figh). Jakarta: Kencana.

Ali, A. (1996). Menguak Tabir Hukum (Suatu Kajian Filosofis dan Historis. Jakarta: Chandra Pratama.

Amiruddin, Z. (2009). Ushul Fiqih. Yogyakarta: Penerbit Teras.

an Nabhânî, T. (2003). Asy-Syakhshiyyah alIslâmiyyah (Vol. 3). Beirut: Dâr alUmmah.

an Nadawî, 'Alî Ahmad. (1999). Maushû'ah alQawấ'id wa adh-Dhawâbith al-Fighiyyah al-Hâkimah li al-Mu'âmalât al-Mâliyyah fî al-Figh al-Islâmî (Vol. 1). Riyadh: Dâr 'Âlam al-Ma'rifah.

an Naisâbûrî, A. 'Abdullah M. bin 'Abdullah al H. (1990). Al-Mustadrak 'alâ ashShahîhain (Vol. 1). Beirut: Dâr al-Kutub al-'Ilmiyah.

ar Rasytah, A. bin khalîl A. (2000). Taisîr alWushûl ilâ al-Ushûl. Beirut: Dâr alUmmah.

ar Râzî, F. M. bin ‘Umar bin al-Husain. (1994). Al-Ma'âlim fì 'Ilm Ushûl al-Figh. Kairo: Dâr al-Ma' rifah. as Salam, al I. bin 'Abd. (2001). Qawa'id alAhkam fi Mashalihi al-Anam. Beirut: Dâr al-Kutub al-'Ilmiyah.

as Sarakhsî, A. B. M. bin A. bin A. S. (1953). Ushûl as-Sarakhsî (Vol. 2). Hyderabad: Lajnah ihyâ' al-Ma'ârif anNu'mâniyyah.

as Sijistânî, A. D. S. bin al A. bin I. bin B. bin S.

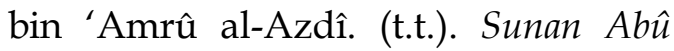
Dâwud (Vol. 3). Beirut: Maktabah al'Ashriyah.

as Subkî, T. 'Abdul W. bin 'Alî. (2003). Jam' aljawâmi' fî Ushîl al-Figh. Beirut: Dâr alKutub al-'Ilmiyah.

asy Syâfi'î, M. bin I. (1940). Ar-Risâlah. Kairo: Maktabah al-Halabî.

asy Syâfi'î, M. bin I. (1990). Al-Umm (Vol. 7). Beirut: Dâr al-Ma'rifah.

asy Syaibânî, A. 'Abdullah A. bin M. bin H. bin H. bin bin A. (2001). Musnad Ahmad (Vol. 36). Beirut: Muassasah arRisâlah.

asy Syâthibî, A. I. I. bin M. bin M. al-Khamrî al-Gharnâthî. (2004). Al-Muwâfaqât fî̀ Ushûl asy-Syarîah. Beirut: Dâr alKutub al-'Ilmiyah.

asy Syaukânî, M. bin 'Alî. (2000). Irsyâd alFukhûl. Riyadh: Dâr al-Fadhîlah.

asy Syinqîthî, M. al A. bin M. al M. bin 'Abd al Q. al J. (1990). Al-Mashâlih al-Mursalah. Madinah: al-Jâmi' ah al-Islâmiyyah.

asy Syuraim, S. bin I. (1994). Al-Minhâj lil Mu'tamir al-Hâjj. Riyadh: Dâr alWathan.

at Tirmidzî, A. 'îsâ M. bin 'îsâ bin S. bin M. bin adh D. (1998a). Sunan at-Tirmidzî (Vol. 3). Beirut: Dar al-Gharb al-Islami.

at Tirmidzî, A. 'îsâ M. bin 'îsâ bin S. bin M. bin adh D. (1998b). Sunan at-Tirmidzî (Vol. 6). Beirut: Dar al-Gharb al-Islami.

ath Thabrânî, A. al Q. S. bin A. bin A. bin M. al L. asy S. (1994). Al-Mu'jam al-Kabîr 
(Vol. 20). Kairo: Maktabah Ibnu Taimiyah.

az Zarkasyî, B. M. bin B. bin 'Abdullah. (1992). Al-Bahr al-Muhîth fî Ushûl al-Figh. (Vol. 5). Kairo: Dâr ash-Shafwah.

az

Zuhailî, M. M. (2006). Al-Qawấ'id alFiqhiyyah wa Tathbîâatihâ fî al-Madzâhib al-Arba'ah. Damaskus: Dâr al-Fikr.

az Zuhailî, W. (1985). Al-Fiqh al-Islâmî wa Adillatuh (Vol. 1). Damaskus: Dâr alFikr.

az Zuhailî, W. (1986). Ushûl al-Figh al-Islâmî (Vol. 1). Damaskus: Dâr al-Fikr.

az Zuhailî, W. (1999). Al-Wajîz fî Ushîl al-Fiqh. Damaskus: Dâr al-Fikr.

Azhari, F. (2014). Qiyas Sebuah Metode Penggalian Hukum Islam. Syariah: Jurnal Hukum Dan Pemikiran, 13(1), 817.

Bakhtiar, B. (2018). Perbedaan dan Persamaan Metode Penemuan Hukum Islam dan Metode Penemuan Hukum Positif. Pagaruyuang Law Journal, 1(2), 220-238.

Bik, M. al-Khudharî. (1969). Ushûl Fiqh. Mesir: Maktabah al-Qabâriyah al-Kubrâ.

Dedi, S. (2018). Konsep Ta'wil Ushuliyyin Dan Relevansinya Dengan Pembaharuan Hukum Islam. JURIS (Jurnal Ilmiah Syariah), 17(1), 1-18.

Djamil, F. (1997). Filsafat Hukum Islam. Jakarta: Logos Wacana Ilmu.

Erwan, E. (2018). Takhrij Al-Furu' Alal Usul Periode Ijtihad Di Masa Shahabat Dan Tabi' in (Kajian Sosiologi-Antropologi Hukum Islam). JURIS (Jurnal Ilmiah Syariah), 17(2), 161-179.

Farghalî, M. M. (1983). Buhûts fî al-Qiyâs. Kairo: Dâr al-Kitâb al-Jama'î.

Hamid, A. (2009). Qiyas Ushuli dan Qiyas Nahwi dalam perspektif historis dan epistemologis. Diambil dari http:/ / repository.uinjkt.ac.id/dspace/ handle/123456789/323

Hamidi, J. (2011). Hermeunitika Hukum, Sejarah, Filasafat dan Metode Tafsir. Malang: UB Press.

Haris, M. (2012). Metodologi Penemuan Hukum Islam. Ulumuna, 16(1), 1-20.

Haroen, N. (1996). Ushul Fiqh I. Jakarta: Logos.

Ismâ'îl, M. M. (1958). Al-Fikr al-Islâm. Beirut: al-Maktabah al-Wa'î.

Kamali, M. H. (2008). Membumikan Syariah: Pergulatan Mengaktualkan Islam (M. Salman, Penerj.). Jakarta: Mizan Publika.

Khallâf, 'Abdul Wahhâb. (1993). Mashâdir atTasyrî” al-Islâmî. Beirut: Dâr al-Qalam.

Khallâf, 'Abdul Wahhâb. (t.t.). 'Ilm Ushûl alFiqh. Kairo: Maktabah ad-Da'wah alIslâmiyyah Syabâb al-Azhar.

Khoirin, N. (2018). Penalaran Ushul Figh Ibnu Hazm (Analisis Penolakan 'Illat dan Qiyas Sebagai Dalil Hukum Islam). 9(1), 57-82.

Kholiq, A. N. (2014). Relevansi Qiyas Dalam Istinbath Hukum Kontemporer. Isti dal : Jurnal Studi Hukum Islam, 1(2), 170-180.

Komite Ulama Khilâfah 'Utsmâniyah. (t.t.). Majallat al-Ahkâm al-'Adliyyah. Karachi: Aram Bagh.

Manzhûr, A. al-F. J. M. bin M. bin. (1981). Lisân al-'Arab. Beirut: Dâr Shâdar.

Mazkur, M. S. (1984). Al-Ijtihad fi Tasyri al Islami. Kairo: Dâr an-Nahdah al'Arabiyah.

Mertokusumo, S. (1996). Bab-bab Tentang Penemuan Hukum. Bandung: Citra Aditya Bakti. 
Munawwir, A. W. (1997). Kamus al-Munawwir Arab-Indonesia Terlengkap. Surabaya: Pustaka Progresif.

Musonnif, A. (2019). Tipologi Epistemologi Hukum Islam (Analisis Metode Penetapan Awal Bulan Hijriyah Tokoh-Tokoh Agama Tulungagung). Ahkam: Jurnal Hukum Islam, 7(1), 1-26.

Muwahid. (2017). Metode Penemuan Hukum (rechtsvinding) oleh Hakim: AlHukama': The Indonesian Journal of Islamic Family Law, 7(1), 224-248.

Mz, S. (2009). Epistemologi Ushul Fikih Al-Syafi'i (Telaah Atas Qiyas Dalam Kitab AlRisalah) (Doctoral, UIN Sunan Kalijaga Yogyakarta). UIN Sunan Kalijaga Yogyakarta. Diambil dari http:// digilib.uin-suka.ac.id/15229/

Naya, F. (2016). Mengurai Titik Temu Antara Istihsan dan Pembaharuan Hukum Islam. TAHKIM, 12(1).

Naya, F. (2017). Membincang Qiyas Sebagai Metode Penetapan Hukum Islam. TAHKIM, 11(1). https:/ / doi.org/10.33477/thk.v11i1.13

Nofrianti, M. (2018). Perkembangan Hukum Islam Pada Masa Umar Ibn Khattab (634-644 M). JURIS (Jurnal Ilmiah Syariah), 17(2), 269-282.

Nur, M. (2016). Rechtsvinding: Penemuan Hukum ( Suatu Perbandingan Metode Penemuan Hukum Konvensional dan Hukum Islam ). Jurnal Ilmiah AlSyir'ah, 2(1).

Penemuan hukum oleh hakim (Rechtvinding). (t.t.). Diambil 31 Oktober 2020, dari http:/ / ditjenpp.kemenkumham.go.id / umum/849-penemuan-hukum-olehhakim-rechtvinding.html

Rifai, A. (2010). Penemuan Hukum Oleh Hakim dalam Perspektif Hukum Progresif. Jakarta: Sinar Grafika.
Riyadi, F. (2016). Kontroversi Zakat Profesi Pesrpektif Ulama Kontemporer. ZISWAF : Jurnal Zakat Dan Wakaf, 2(1), 109-132.

Rohman, H. (2018). Maqasid Al-Syari'ah Mazhab Syafi'i dan Urgensinya dalam Ijtihad Kontemporer. JURNAL HUKUM ISLAM, 188-204.

Rohman, T. (2017). Kontroversi Pemikiran Antara Imam Malik Dengan Imam Syafi'i Tentang Maslahah Mursalah Sebagai Sumber Hukum. International Journal Ihya' 'Ulum al-Din, 19(1), 73-90.

Sahroni, O. (2017). Ushul Fikih Muamalah: Kaidah-kaidah Ijtihad dan Fatwa dalam Ekonomi Islam. Depok: Rajawali Pers.

Sakirman, S. (2018). Metodologi Qiyas Dalam Istinbath Hukum Islam. YUDISIA: Jurnal Pemikiran Hukum dan Hukum Islam, 9(1), 37-55.

Sarwat, A. (2019). 'Illat Hukum. Jakarta: Rumah Fiqih Publishing.

Simbolon, P. (2020). Metode Istinbat Dalam Kitab Tawdih Al-Ahkam Min Bulugh Al-Maram Karya Al-Bassam (13461423 H). JURIS (Jurnal Ilmiah Syariah), 19(1), 31-44.

Sudirman. (2018). Figh Kontemporer (Contemporary studies of figh). Yogyakarta: Deepublish.

Sulistiani, S. L. (2018). Perbandingan Sumber Hukum Islam. Tahkim (Jurnal Peradaban dan Hukum Islam), 1(1).

Surono, Y. (2012). Qiyas Sebagai Metode Hukum Islam. Ar-rusyd, 2(2), 1-20.

Suryani, I. (2018). METODE FATWA MAJELIS ULAMA INDONESIA. JURIS (Jurnal Ilmiah Syariah), 9(2), 175184.

Syaltût, M. (1996). al-Islâm: 'Aqîdah wa Syarî'ah. Kairo: Dâr al-Qalam. 
Tajudin, J. H. (2017). Istihsan; Analisis Historis Pemikiran Imam As-Syafi'i. SANGAJI: Jurnal Pemikiran Syariah Dan Hukum, 1(1), 71-84.

Usman, M. (1997). Kaidah-kaidah Ushuliyah dan Fiqhiyah. Jakarta: RajaGrafindo Persada.

Yunus, M. (1973). Kamus Arab-Indonesia. Jakarta: Yayasan Penyelenggara Penterjemah/Pentafsiran al Qur'an.
Zahrah, M. A. (1973). Ushûl Fiqh. Beirut: Dâr al-Fikr al'Arabî.

Zaidah, Y. (2018). Model Hukum Islam: Suatu Konsep Metode Penemuan Hukum melalui Pendekatan Ushuliyyah. Syariah: Jurnal Hukum Dan Pemikiran, 17(2), 143-159. 